\title{
Implementasi Teknologi Tepat Guna untuk Mengatasi Permasalahan IRT Ramuan Madura di Kabupaten Sumenep
}

\author{
Abdulkadir Rahardjanto ${ }^{1 *}$, N. Nurwidodo², M. Mas'odi ${ }^{3}$ \\ 1,2,3 Universitas Muhammadiyah Malang
}

A R T I C L E I N F O

Article history:

Received 20 August 2019

Received in revised form

10 September 2019

Accepted 30 October 2019

Available online 30

November 2019

\section{Kata Kunci:}

Ramuan Madura, ramuan tradisional, Kabupaten

Sumenep, teknologi tepat guna

Keywords:

Madurese herbal

ingredients, traditional

herbal ingredients, Sumenep

regency, appropriate

technology

\begin{abstract}
A B S T R A K
Kegiatan pengabdian terkait dengan ramuan Madura, yang berorientasi pada terciptanya kemandirian masyarakat, sebagai hasil introduksi pengetahuan dan teknoligi tepat guna (TTG) sangat diperlukan. Artikel ini bertujuan menganalisis implementasi pemanfaatan teknologi tepat guna berbasis solar cell untuk mengatasi permasalahan IRT Ramuan Madura di Kabupaten Sumenep. Mitra PPTTG ini, yaitu Kelompok Ramuan Madura "Gilang Emas Group" dan Kelompok Ramuan Madura "Maju Jaya". Instrumen kegiatan meliputi materi presentasi, produk, alat dokumentasi, buku catatan, dan instrumen evaluasi. Metode pengabdian adalah survey, demonstrasi, dan praktek langsung, dan evaluasi. Data dikumpulkan dengan terlibat langsung dalam aktivitas mitra. Data dianalisis secara deskriptif. Kegiatan dianggap berhasil bila mitra mahir menggunakan TTG, keterlibatan dan keaktifan mitra $\geq 75 \%$, ada peningkatan kuantitas dan kualitas produk, serta ada peningkatan omzet. Berbagai kegiatan dilakukan pengabdi, yaitu koordinasi dan konsolidasi tim, serta penyamaan persepsi dengan mitra, pendesainan, penyiapan, dan pembuatan, penyerahan TTG, pelatihan, dan pemanfaatan TTG oleh mitra, serta monitoring dan evaluasi. Dpat disimpulkan bahwa kegiatan pengabdian telah dilaksanakan dengan sangat baik, sesuai dengan target yang telah ditetapkan.
\end{abstract}

\section{A B S T R A C T}

Community service activities related to Madurese herbal ingredients, which are oriented to the creation of community independence, as a result of the introduction of knowledge and appropriate technology (TTG) are very necessary. The purpose of this article is to analyze the implementation of the use of appropriate This article aims to analyze the implementation of the use of appropriate technology to overcome the problem of domestic industry of Madurese herbal ingredients in Sumenep Regency. These program partners, namely the "Gilang Emas" Group and the "Maju Jaya" Group. Instrument activities include presentation materials, products, documentation tools, notes, and evaluation instruments. Service methods are survey, demonstration, and direct practice, and evaluation. Data is collected by being directly involved in partner activities. Data were analyzed descriptively. Activities are considered successful if the partners are proficient using TTG, partner involvement and activity is $\geq 75 \%$, there is an increase in the quantity and quality of products, and there is an increase in turnover. A variety of activities are carried out, including coordination and team consolidation, as well as equalizing perceptions with partners, designing, preparing, and making, submitting TTG, training, and utilizing TTG by partners, as well as monitoring and evaluation. It was concluded that the community service activities had been carried out very well, in accordance with the targets set.

\footnotetext{
* Corresponding author.

E-mail addresses: Abdulkadir23@gmail.com (Abdulkadir Rahardjanto)
} 


\section{Pendahuluan}

Sistem pengobatan tradisional masih menjadi pilihan mayoritas penduduk di Indonesia. Data hasil Riset Kesehatan Dasar tahun 2013 (Riskesdas) menunjukkan sebesar 35,2\% masyarakat Indonesia masih menyimpan dan menggunakan obat tradisional. Sejumlah $49 \%$ obat tradisional yang digunakan berbentuk ramuan. Pengobatan tradisional merupakan salah satu kekayaan bangsa yang berwujud kearifan lokal (local wisdom dan indigenous knowledge). Kearifan lokal yang terjaga, mendukung kelestarian penggunaan ramuan obat tradisional secara turun temurun (Andriyanti \& Wahjudi, 2016; Savitri, 2016; Shanthi, Jumari, \& Izzati, 2014). Berbagai etnis memanfaatkan tumbuhan sebagai etnomedisin dengan keunikan ramuan dan cara penyajian untuk menunjukkan tingginya pengetahuan etnis lokal tentang tumbuhan obat (Pelokang, Koneri, \& Katili, 2018; Simanjuntak, 2016; Susila, Tellu, \& Tangge, 2017).

Pembuatan ramuan obat tradisional oleh penyehat tradisional umumnya didasarkan pada akumulasi pengetahuan lokal dan kebijakan yang telah dipatuhi sebagai tradisi dan hukum adat yang diwariskan dari pendahulu (Agil, Wahyuni, Studiawan, \& Rakhmawati, 2019; Astana \& Nisa, 2018), atau para leluhur masyarakat. Masyarakat menganggap ramuan merupakan pengobatan yang lebih aman dibandingkan dengan pengobatan modern (Prastiwi, 2018). Begitu pula dengan ramuan Madura. Sejak beratus-ratus tahun yang lalu masyarakat Madura telah mengolah ramuan tradisional warisan budaya lokal dan identitas Madura (Nurlaila, 2013; Satriyati, 2016, 2017; Susanti, 2016).

Ramuan Madura merupakan kreativitas intelektual masyarakat Madura yang berupa metode ramuan dengan formula dan komposisi bahan yang berupa tumbu- tumbuhan, akar-akaran yang dianggapnya memiliki khasiat khusus dalam praktik pengobatan (Ratnawati, Handayani, \& Rakhmawati, 2013). Orang Madura menyebutnya istilah jhemo, (selanjutnya digunakan istilah jhemo) yaitu minuman obat yang terbuat dari tanaman obat seperti dedaunan, bunga, akar dan kulit kayu yang ditumbuk atau direbus guna menghasilkan jhemo cair, serbuk, plintiran (Ratnawati, Jurianto, \& Ali, 2017).

Ramuan Madura mempunyai kekhasan tersendiri antara lain rasanya pahit segar, bau harum yang beraroma khas rempah-rempah. Masyarakat selama ini mengenal ramuan Madura mempunyai khasiat untuk kesehatan, baik untuk perawatan maupun pengobatan (Limananti \& Triratnawati, 2003; Mudjijono, Herawati, Munawaroh, \& Sukari, 2014). Setiap orang mendengar ramuan Madura yang terbayang adalah keampuhannya. Dari semula kemujaraban ramuan Madura dianggap setara dengan jamu yang dikembangkan oleh para datu dan dukon, yang pada dasarnya menggunakan simplisia atau bahan penyusun ramuan yang serupa (Handayani, 2008). Konsepsi pencegahan dan promosi kesehatan tradisional Madura memiliki unsur-unsur upaya kesehatan yang sebagian tidak sama dengan konsepsi pencegahan dan promosi kesehatan menurut ilmu kesehatan masyarakat (modern), akan tetapi sebagian yang lain memiliki unsur- unsur yang sama. Sekalipun demikian tidak bertentangan antara kesduanya, bahkan memiliki tujuan yang sama ialah memperoleh derajat kesehatan yang setinggi-tingginya (Nurwidodo, 2006).

Sebagai warisan nenek moyang, maka sudah sepatutnyalah kita melestarikan ramuan tradisional (Satriyati, 2017). Namun sejalan dengan laju perkembangan teknologi, peradaban dan jumlah penduduk, maka konsumen ramuan tradisional mulai berkurang karena mereka cenderung untuk memilih obatobatan kimia yang lebih praktis dari jamu trdisional. Berbeda dengan ramuan tradisional yang pada awalnya diproduksi untuk memenuhi kebutuhan sendiri, dan konsumennya kebanyakan berada di pedesaan, sehingga semakin langka orang yang dapat membuat ramuan (Widiyanti, 2005).

Secara umum, kegiatan pembuatan ramuan tradisional Madura hanya sebagai pekerjaan sampingan untuk menopang ekonomi bagi keluarganya (Arifin, Yuliawati, \& Syafrawi, 2016). Terkait dengan ramuan Madura, teridentifikasi beberapa temuan masalah yang diprioritaskan untuk dicarikan solusinya. Temuan tersebut berupa pemanfaatan teknologi yang masih lemah, sistem pemasaran, distribusi dan dan promosi belum tertata dengan baik (Safrizal \& Kurriawati, 2016). Pembuatan ramuan Madura perlu pula mengantisipasi perkembangan teknologi (Zaman, 2009). Hal ini karena secara umum di Indonesia, teknologi yang digunakan dalam membuat ramuan masih menggunakan teknologi yang masih sederhana. Pembuatan ramuan dengan cara seperti ini sangat tidak efektif karena memakan waktu relatif lama serta sangat memakan tenaga (Widiyanti, 2005). Ramuan madura harus mengadopsi teknologi sebagai upaya untuk menjaga kelestariannya, sebaga sebagaimana menerut Aladjai (2019) perkembangan teknologi dan pengetahuan seringkali melenyapkan pengetahuan tradisional dengan alasan tidak teruji klinis, tidak akademis, dan tidak ada legitimasi.

Ramuan tradisional pada awalnya dibuat oleh masyarakat secara tradisional untuk pengobatan sendiri atau lingkungan terbatas. Kemudian berkembang menjadi industri rumah sejak pertengahan abad ke 20, dan telah diproduksi secara masal baik oleh industri kecil maupun industri obat tradisional yang lebih modern dengan mengikuti perkembangan teknologi dalam pembuatan obat tradisional. Dalam 
rangka perkembangan di bidang kesehatan yang sejalan dengan perkembangan ekonomi, sosial, budaya, serta ilmu dan teknologi diperlukan penyediaan ramuan yang aman, dan benar khasiatnya (Mudjijono et al., 2014). Pemasaran yang dilakukan di dalam negeri tersebar di beberapa wilayah Jawa Timur (khususnya Surabaya, Malang), Jawa Tengah dan Jakarta. Pemasaran ramuan Madura ke luar negeri (ekspor) jamu tradisional Madura belum banyak atau masih terbatas diakukan (Burhan \& Mustajib, 2010). Ramuan Madura diperjualbelikan di negara-negara lain seperti Arab Saudi, Malaysia, Korea, dan Jepang (Fatmawati, Anwari, Harun, \& Alwiyah, 2013) .

Menurut Muslimin et al. (2009) dari sisi perekonomian, industri ramuan tradisional telah berkontribusi sangat besar bagi pendapatan nasional, peningkatan kesejahteraan masyarakat dan penyediaan lapangan kerja. Bahan baku yang hampir sekitar 99\% yang digunakan merupakan produk dalam negeri dinilai mampu membawa multiplier effect yang cukup signifikan dalam pertumbuhan perekonomian di Indonesia mulai dari sektor hulu (pertanian) hingga sektor hilir yang meliputi perindustrian dan perdagangan.

Namun di balik besarnya manfaat dan potensi tersebut masih banyak kendala yang dihadapi oleh industry ramuan tradisional, terlebi b bagi industri skala kecil atau industri rumah tangga (IRT). Hal ini dikarenakan kemampuan dan daya saing produk dari usaha kecil yang belum terstandarisasi. Selain itu teknologi pembuatan ramuan yang mereka gunakan masih sangat terbatas atau belum canggih (Muslimin et al., 2009). Sampai saat ini wirausaha yang memiliki potensi untuk berkembang di wilayah Madura adalah industri rumah tangga (IRT), salah satunya ramuan (Retnowati \& Kurniawati, 2016). Industri rakyat atau industri kecil, termasuk jamu/ramuan mempunyai ciri-ciri, yaitu produksi banyak menggunakan pekerjaan, tenaga, menggunakan alat-alat dan teknik sederhana, produksi dilakukan di rumah dan upah pekerjanya yang rendah (Widiyanti, 2005).

Sehubungan dengan, perlu upaya pengabdian yang terkait dengan ramuan Madura. Dalam konteks yang lebih spesifik, kami melaksanakan pengabdian Program Penerapan Teknologi Tepat Guna (PPTTG) yang disponsori oleh Kemenristek Dikti tahun 2019. Mitra yang terlibat dalam PPTTG ini adalah dua kelompok masyarakat. Kelompok pertama bernama "Gilang Emas" dan kelompok yang kedua bernama "Maju Jaya". Keduanya berdomisili di Kabupaten Sumenep. Kedua mitra merupakan produsen ramuan Madura dengan omset relatif kecil, melakukan produksi jamu dalam skala kecil (bahkan masih dalam skala rumah tangga), menggunakan peralatan yang sangat sederhana, dan dengan jangkauan pemasaran yang masih terbatas. Pemasaran jamu masih terbatas hanya di kawasan Sumenep saja.

Solusi yang ditawarkan melalui program ini terhadap empat permasalahan utama mitra Ramuan Madura adalah dengan mengembangkan/memproduksi alat produksi jamu atau teknologi tepat guna (TTG) pengolahan/produksi ramuan, mensosialisasikan, melatih, mendampingi produksi, pengemasan produk, pemasaran, dan melakukan perawatan alat/TTG. Solusi dari permasalahan tidak optimalnya kualitas dan kuantitas produksi adalah dengan menyediakan TTG Paket Mesin Pembuat Ramuan Sistem Evaporator (yang terdiri atas 1. Mesin Penggiling/Mesin Parut, 2. Alat Peras Manual, 3. Bejana Evaporator, dan Sealer). TTG ini memadukan sistem pembersihan bahan, penggilingan dan pengolahan bahan yang mampu menghasilkan produk jamu yang lebih berkualitas, baik dalam bentuk cair, serbuk yang lebih halus tanpa melalui pemanasan konvensional agar kualitas tetap terjaga, dan/atau padatan). TTG yang dihasilkan dan ditransfer kepada mitra bersifat lebih praktis, sesuai standar pengolahan yang ditetapkan dinas kesehatan, dan highienis daripada peralatan konvensional yang dipakai oleh mitra selama ini.

Pengabdian ini berorientasi pada terciptanya kemandirian masyarakat, sebagai hasil dari introduksi pengetahuan dan TTG. Tujuan dari artikel ini adalah menganalisis implementasi teknologi tepat guna untuk mengatasi permasalahan IRT Ramuan Madura di Kabupaten Sumenep.

\section{Metode}

Terdapat beberapa pihak yang terlibat dalam PPTTG ini. Beberapa pihak tersebut, antara lain (1) tim pengusul PPTTG yang merancang TTG untuk mengatasi permasalahan pengolahan dan penjualan ramuan oleh pedangan ramuan tradisional di Sumenep; (2) Direktorat Penelitian dan Pengabdian pada Masyarakat (DP2M) Universitas Muhammadiyah Malang sebagai lembaga Litbang di UMM; (3) Bengkel Mesin Karya Brawijaya yang beralamat di Jl. Sidomakmur 76 A, Mulyoagung, Dau, Malang yang dilibatkan dalam pembuatan alat; (4) mitra PPTTG, yaitu Kelompok Ramuan Madura "Gilang Emas" dan Kelompok Ramuan Madura "Maju Jaya” yang akan menggunakan teknologi hasil pengembangan tim pengusul.

Tahapan yang akan dilaksanakan dalam program TTG ini adalah sebagai berikut. (1) Pengidentifikasian jenis usaha ramuan tradisional Madura yang dilakukan oleh masyarakat di Kabupaten Sumenep. (2) Pemilihan salah satu jenis usaha yang akan dianalisis lebih lanjut permasalahan dan alternatif solusi yang dapat ditawarkan, yaitu produksi ramuan tradisional ramuan Madura yang dijalankan oleh Bapak Abdus Samad dan Bapak Abdul Rahem di Sumenep. (3) Identifikasi persoalan yang 
dihadapi oleh produsen ramuan tradisional melalui kegiatan observasi dan wawancara. (4) Analisis alternatif solusi untuk memecahkan persoalan-persoalan penjual ramuan dengan memanfaatkan teknologi tepat guna. (5) Pendesainan TTG. (6) Penyiapan dan pengadaan teknologi tepat guna, yang meliputi alat produksi ramuan, mesin pengemas, serta IPTEK untuk pemasaran. (7) Pelatihan dan pendampingan pemanfaatan teknologi dan pemasaran oleh mitra. (8) Monitoring dan evaluasi penggunaan teknologi yang telah dikembangkan dan diadakan pada aspek peningkatan kualitas dan kuantitas produk jamu serta aspek income yang diperoleh mitra. (9) Pendampingan perawatan TTG.

Mesin penggiling bahan baku jamu merupakan mesin yang dikembangkan untuk mengolah bahan dasar pembuatan ramuan tradisional menjadi bubuk jamu dengan tekstur halus. Mesin ini dapat menghaluskan bahan-bahan mentah jamu menjadi serbuh halus dengan waktu yang lebih cepat dari proses produksi manual. Mesin di desain mampu memiliki tingkat produksi $25 \mathrm{~kg} / \mathrm{hari}$. Bahan dasar mesin adalah stainless steel sehingga sesuai standar higienitas (keamanan produk). Pengoperasian mesin tersebut menggunakan bantuan listrik dan kompor LPG. Komponen utama dari mesin adalah penggiling yang tersusun atas rotor yang berputar karena daya listrik yang masuk ke dalam mesin. Dalam sistem peralatan proses produksi tersebut, terdapat beberapa komponen utama penyusun sistem produksi tersebut, yaitu grinder, press manual, bejana masak, dispenser, evaporator, dan alat pengemas (packaging).

Berikut merupakan prosedur kerja yang akan dilaksanakan untuk mendukung realisasi metode yang ditawarkan dalam program ini. (1) Mencatat jenis ramuan, jenis bahan, dan proses serta cara produksi ramuan dari kedua kelompok masyarakat mitra. (2) Mencatat beberapa terobosan dalam proses produksi ramuan yang diprediksi mampu meningkatkan kualitas dan kuantitas produk ramuan yang dihasilkan. (3) Mendesain alat produksi ramuan sesuai dengan data yang telah diperoleh dari langkah 1 dan 2. (4) Memproduksi dua unit alat produksi ramuan. Langkah ini dilakukan di Bengkel Mesin Karya Brawijaya yang beralamat di Jl. Sidomakmur 76 A, Mulyoagung, Dau, Malang. (5) Mengujicoba alat produksi ramuan yang telah dibuat. (6) Mendistribusikan TTG ramuan kepada mitra. Setiap kelompok masyarakat mendapatkan satu unit TTG ramuan. (7) Mengadakan pelatihan penggunaan alat produksi ramuan kepada kedua mitra kelompok masyarakat yang terlibat dalam program ini. (8) Pendampingan produksi dan pengemasan.

Berikut merupakan partisipasi mitra dalam pelaksanaan program yang diusulkan. (1) Mitra melibatkan diri dan berkomitmen penuh dalam program penerapan TTG ini. (2) Mitra menyediakan ruangan produksi sesuai dengan kebutuhan yang diperlukan untuk instalasi TTG yang diaplikasikan. (3) Mitra bersedia menggunakan dan merawat peralatan yang telah diberikan. (4) Mitra bersedia mengikuti pelatihan perawatan peralatan produksi dan melakukan reparasi sendiri (perawatan mandiri) atas permasalahan yang mungkin timbul terhadap teknologi yang diinstalasikan.

Program ini merencanakan evaluasi dan monitoring yang akan selalu dilakukan sejak tahapan persiapan implementasi, implementasi awal, pertengahan hingga akhir implementasi untuk melihat kendala yang ditemukan dan upaya mengatasinya serta untuk mendorong terwujudnya keberlanjutan program. Kegiatan ini dikatakan berhasil dengan indikator, yaitu 1) dihasilkannya peralatan/mesin TTG pengolahan ramuan Madura yang berjumlah 2 paket (masing-masing terdiri atas grinder, alat press, dan vacuum. 2) dihasilkannya berbagai kemasan beserta alat sealer. 3) dihasilkannya strategi pemasaran. 4) 85\% peserta yang terlibat/mitra memahami sistem kerja TTG yang dihasilkan dan dapat mengoperasikan dengan baik. 5) adanya peningkatan jumlah produksi dan omset dari selama ini. Keberlanjutan program akan ditempuh dengan pengembangan upaya penguatan usaha produksi ramuan tradisional (empowering) dan perluasan usaha (advocation) melalui pengembangan jalur pemasaran dan diversifikasi produk jenis dan bentuk ramuan tradisional yang diproduksi.

\section{Hasil dan Pembahasan}

Berdasarkan Tahapan yang akan dilaksanakan dalam program TTG ini adalah sebagai berikut :

\section{Koordinasi dan Konsolidasi Tim, serta Penyamaan Persepsi dengan Mitra}

Tim PPTTG telah melaksanakan kegiatan koordinasi dan konsolidasi internal, sebagaimana disajikan pada Gambar 1. Kegiatan ini bertujuan untuk penyamaan persepsi antar tim, perencanaan alur kegiatan, perencanaan jadwal, dan pembagian tugas masing-masing. Kegiatan telah terlaksana dengan sangat baik. Hasil kegiatan berupa adanya kesepakatan, catatan kegiatan, foto dokumentasi dan presensi kegiatan. Tim membagi tugas terkait kegiatan (a) analisis permasalahan mitra yang akan dibantu TTG, (b) penetapan solusi, (c) desain TTG, (d) perakitan TTG, (e) pelatihan dan pendampingan mitra, dan (f) publikasi (publikasi media massa dan publikasi ilmiah/jurnal). 


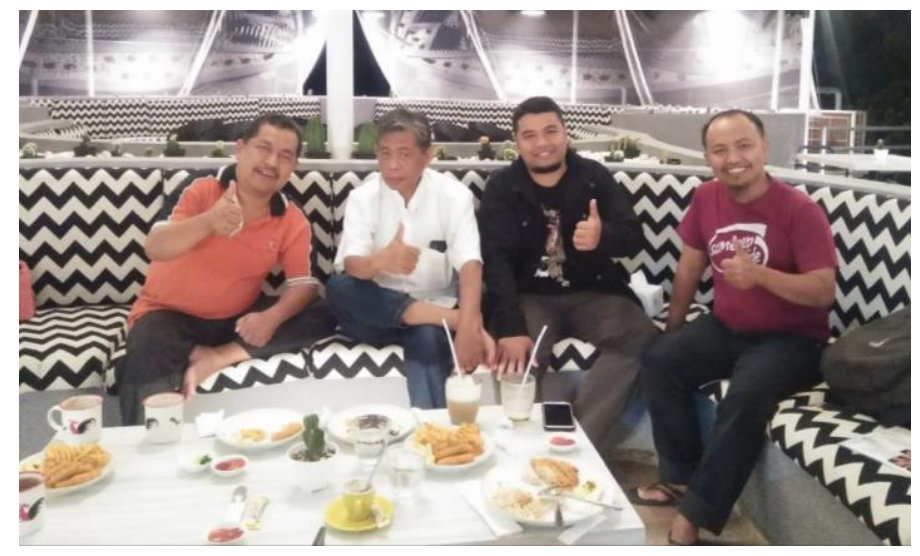

Gambar 1. Tim PPTTG melaksanakan kegiatan koordinasi dan konsolidasi internal

Tim juga melakukan penyamaan persepsi dengan mitra, sebagaimana dibuktikan pada Gambar 2. Hasil kegiatan adalah informasi mengenai mitra. Kelompok Ramuan Madura "Gilang Emas" diketuai oleh Bapak Abdus Samad, beralamat di Dusun Raas Desa Panagan Kecamatan Gapura Kabupaten Sumenep Jawa Timur. Pusat kegiatan dan pusat produksi dari kelompok masyarakat ini beralamat di Jl. Raya Gapura RT 01 RW 01, Desa Panagan, Kecamatan Gapura, Sumenep. Home industry ini memasarkan hasil produksinya dengan cara menitipkan di kios-kios jamu, dijajakan keliling wilayah sekitar mereka, dan menitipkan di pasar kecamatan. Sesuai dengan hasil observasi dan wawancara, proses produksi jamu masih menggunakan teknologi yang sangat sederhana, masih manual dan jumlah produksi masih rendah dan penghasilan sangat kecil yaitu <Rp. 1.000.000/bulan/perorang. Sebagaimana umumnya home industri jamu tradisonal, kegiatan di Kelompok Ramuan Madura "Gilang Emas" bertumpu pada kegiatan pengolahan seperti pemilahan bahan atau pengeringan bahan, pengolahan dan pemasaran hasil. Kelompok home industry memiliki anggota yang berprofesi kesemuanya sebagai petani. Kegiatan membuat ramuan tradisional dilakukan hanya sebagai sampingan, untuk membantu menopang perekonomian keluarga.

Kelompok Ramuan Madura "Maju Jaya" diketuai oleh Bapak Abdul Rahem, beralamat di Desa Longos Kecamatan Gapura Kabupaten Sumenep. Kelompok masyarakat ini merupakan kelompok penjual ramuan tradisional yang penjualannya secara keliling, membuka kios ramuan, dan memasarkannya di pasar kecamatan. Oleh karena itu, wilayah pemasarannya sangat terbatas dan pada akhirnya penghasilanakan sangat kecil yaitu $<$ Rp. 1.000.000/bulan/perorang.

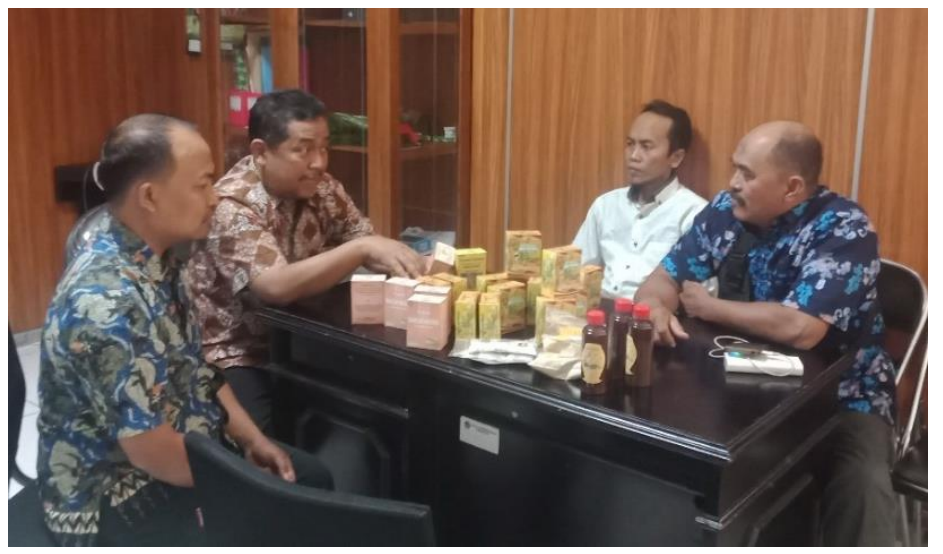

Gambar 2. Kegiatan diskusi dan penyamaan persepsi dengan mitra

\section{Pendesainan teknologi tepat guna, penyiapan, dan pembuatan/perakitan}

Pendesainan TTG ramuan Madura dilakukan oleh tim bersama dengan pihak bengkel Karya Brawijaya dengan mempertimbangkan berbagai hal, seperti bahan, peralatan, metode dan perakitan, dan gambaran proses kerja. Tim Bersama pihak bengkel selanjutnya melakukan proses pembuatan/perakitan. Kegiatan ini seperti disajikan pada Gambar 3. 


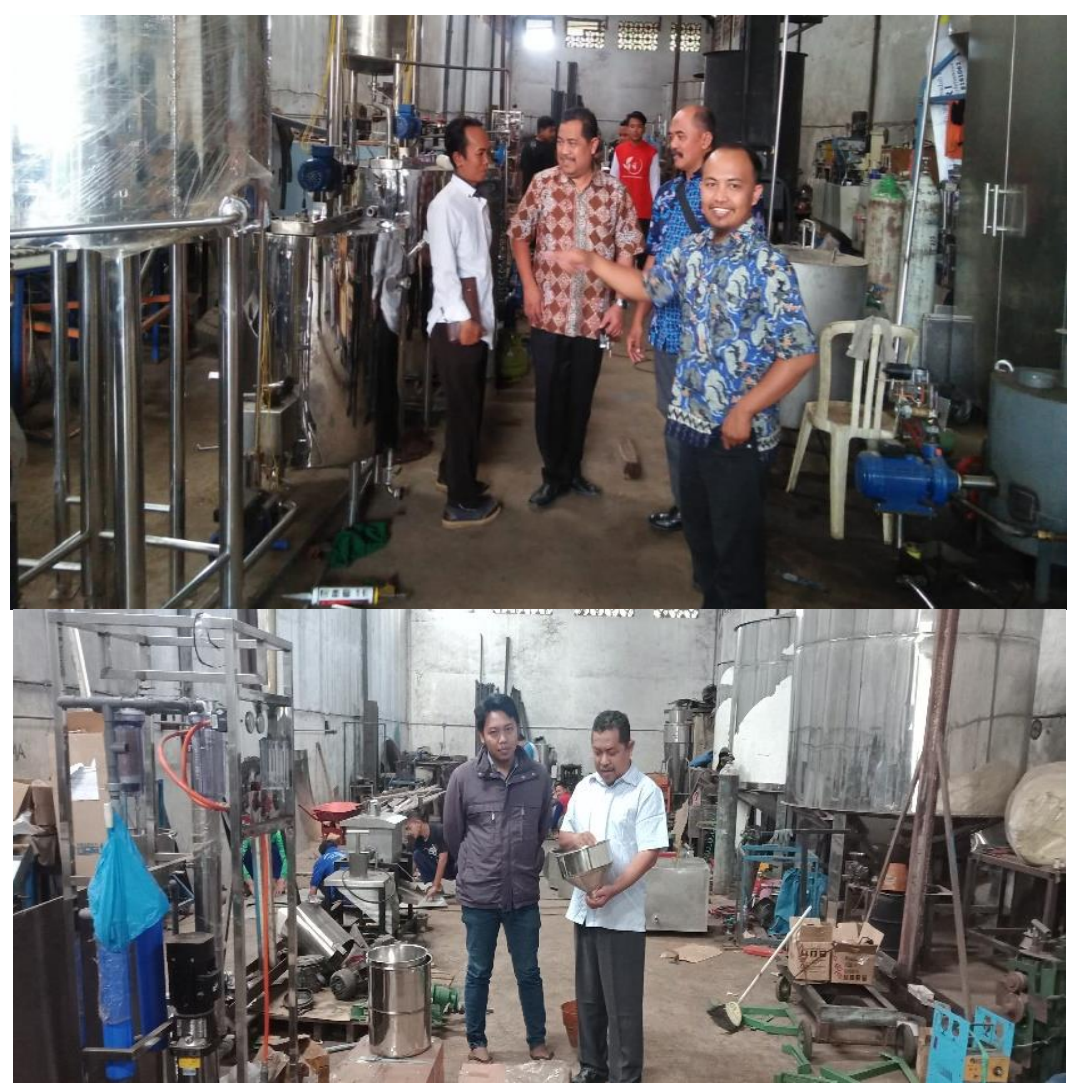

Gambar 3. Kegiatan pendesainan TTG, penyiapan, dan pembuatan/perakitan

3. Penyerahan TTG, pelatihan, dan pemanfaatan teknologi oleh mitra

TTG telah selesai dibuat/dirakit, selanjutnya diserahkan kepada mitra, seperti pada Gambar 4. Mitra diberikan pelatihan bagaimana pengoperasiannya, sebagaimana ditunjukkan pada Gambar 5 .

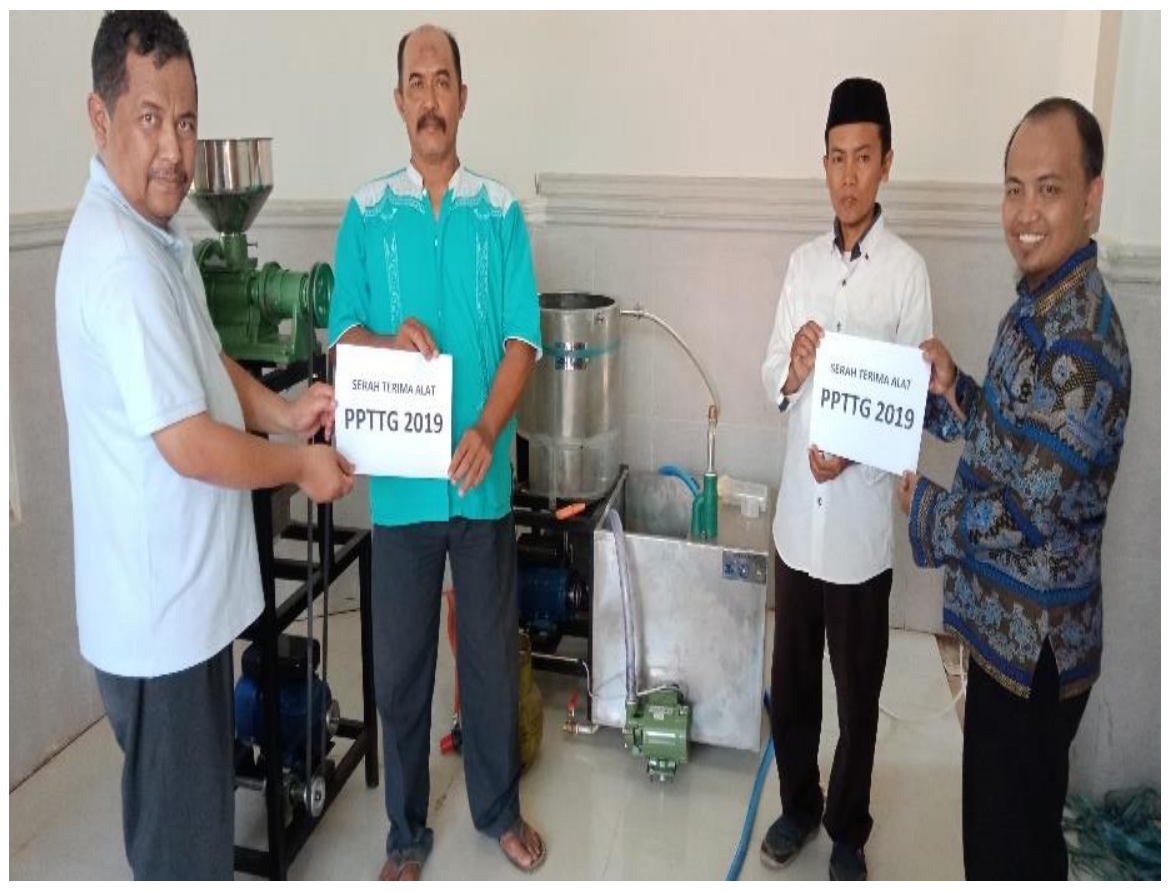

Gambar 4. Penyerahan TTG 


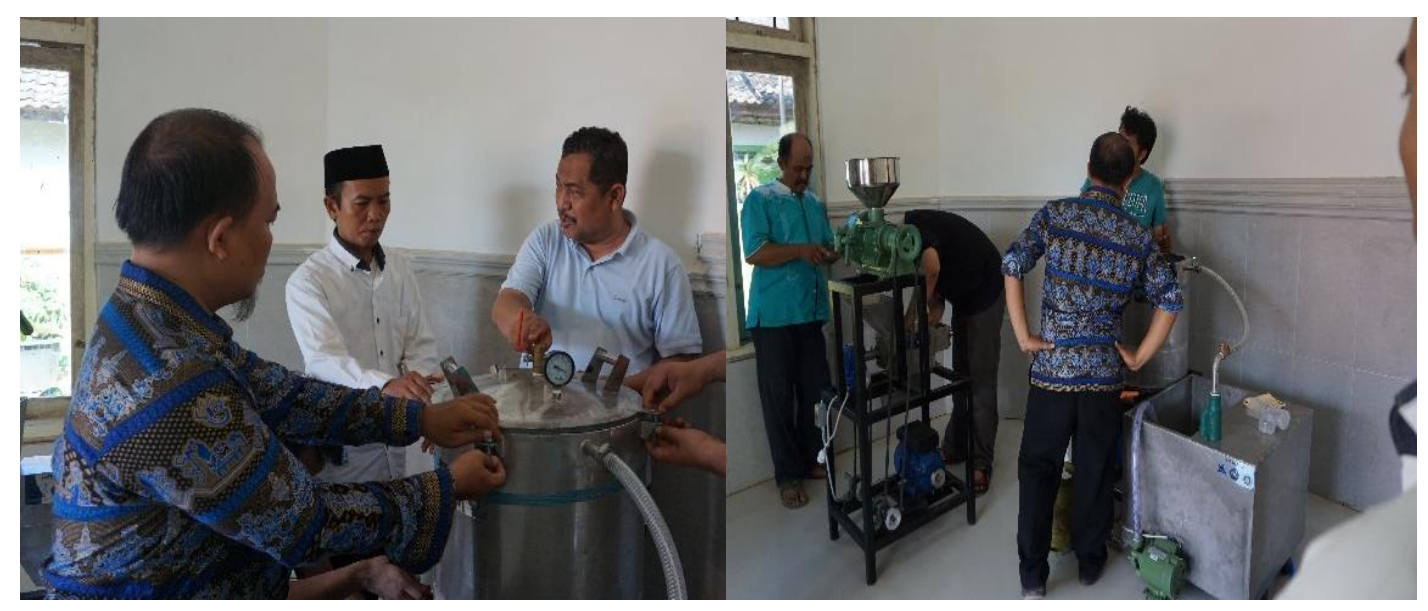

Gambar 5. Pelatihan pengoperasian TTG

Adapun spesifikasi TTG, yaitu (a) Mesin Penggiling atau Parut Empon-empon dan sekaligus peras; kapasitas: 20kg/jam, grinding wheel: 6", penggerak: dinamo listrik/engine bensin, rangka: pipa besi, dimensi total: 30 × 70 x 80, sistem peras: ulir, rangka: siku besi, silinder pres: plat SS, dan saringan: plat lubang SS. (b) Bejana evaporator; kapasitas: 20 liter/proses, sistem vacuum: vacuum jet (300 Watt/220v), sumber panas: burner (LPG), material tabung: plat SS, dan dimensi total : 60 × 30 × 90 .

Adapun deskripsi kerja /proses TTG yang telah diberikan yaitu 1. Cuci bersih empon-empon; 2 . Giling atau parut kelapa sampai halus (pemilihan grinder atau parut sesuai permintaan konsumen); 3 . Hasil gilingan atau parutan kemudian di ambil sarinya; 4. Siapkan api, seting suhu $80^{\circ} \mathrm{C}^{\prime} \mathrm{5}$. Rebus sarinya dan ditambahkan dengan air dan gula sesuai komposisi; 6. Proses kurang lebih 2 jam; dan 7. Biarkan dahulu sampai dingin baru dipacking.

Tim juga melakukan pendampingan terkait dengan manajemen usaha (Gambar 6), dimana tim juga menghadirkan pemateri yaitu dosen dari STKIP PGRI Sumenep. Hal ini sangat penting untuk meningkatkan keprofesionalan mitra dalam menjalankan usahanya.

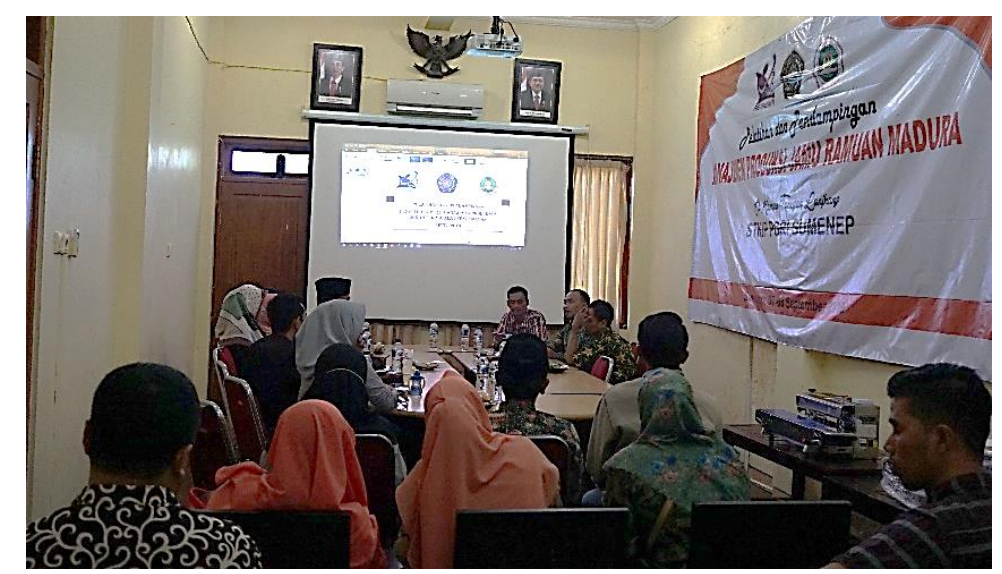

Gambar 6. Kegiatan pendampingan terkait dengan manajemen usaha

Tim juga melakukan pendampingan dalam hal pengurusan Sertifkat Pangan Industri Rumah Tangga atau P-IRT (Gambar 7). Tim melakukan penggalian informasi dan konsultasi mengenai syaratsyarat/mekanisme pengajuan P-IRT ke Dinas Kesehatan Kabupaten Sumenep. Bersama dengan mitra, tim juga telah melengkapi berbagai persyaratan pengajuan P-IRT didampingi oleh Bapak Saiful Bahri (Staf bagian P-IRT di Dinkes Sumenep). 


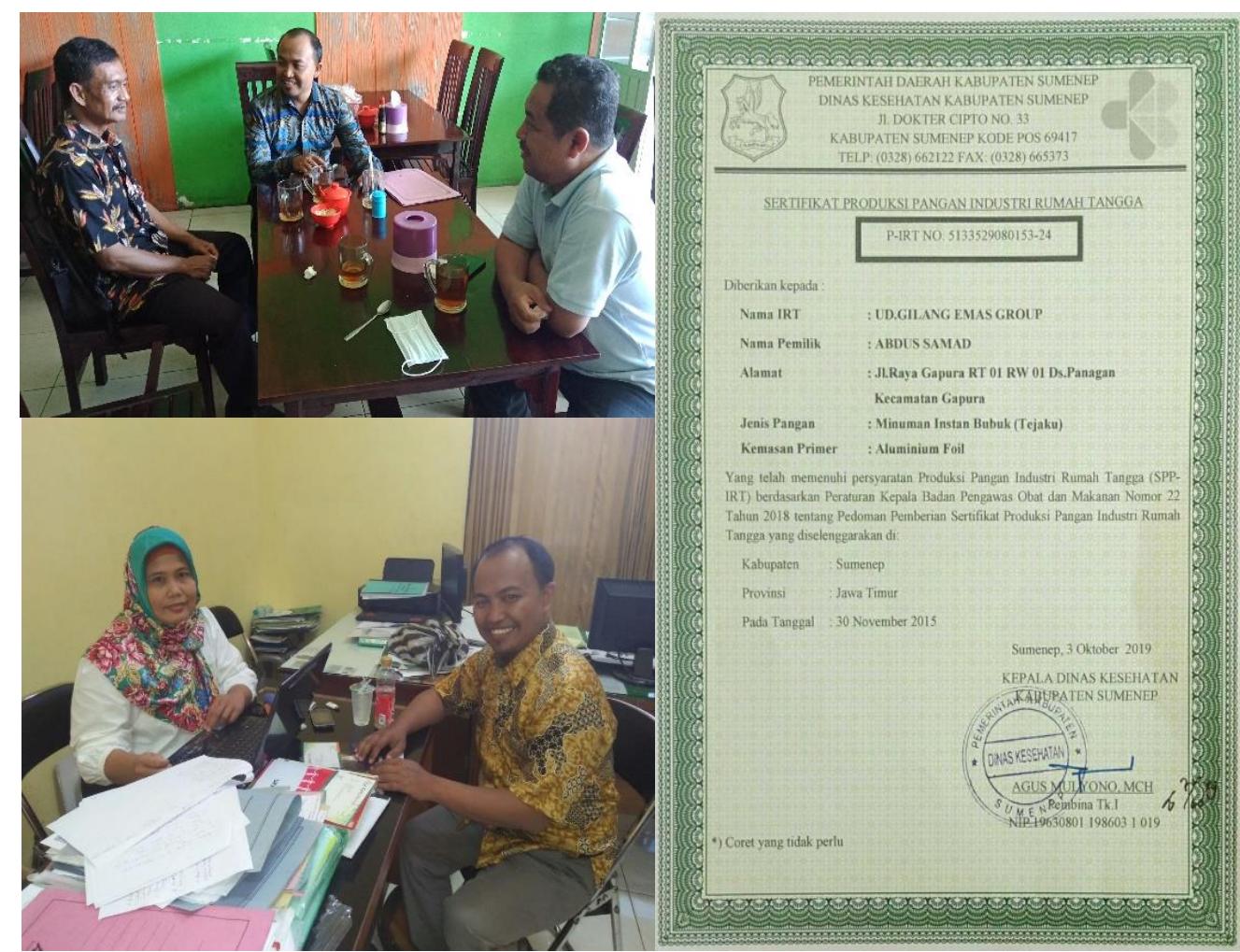

Gambar 7. Pengurusan Sertifkat Pangan Industri Rumah Tangga (P-IRT) dan P-IRT yang diterima

Tim juga melakukan pendampingan pengemasan, membantu mendesain kemasan dan menyediakan alat pres/sealing machine, seperti pada Gambar 8.

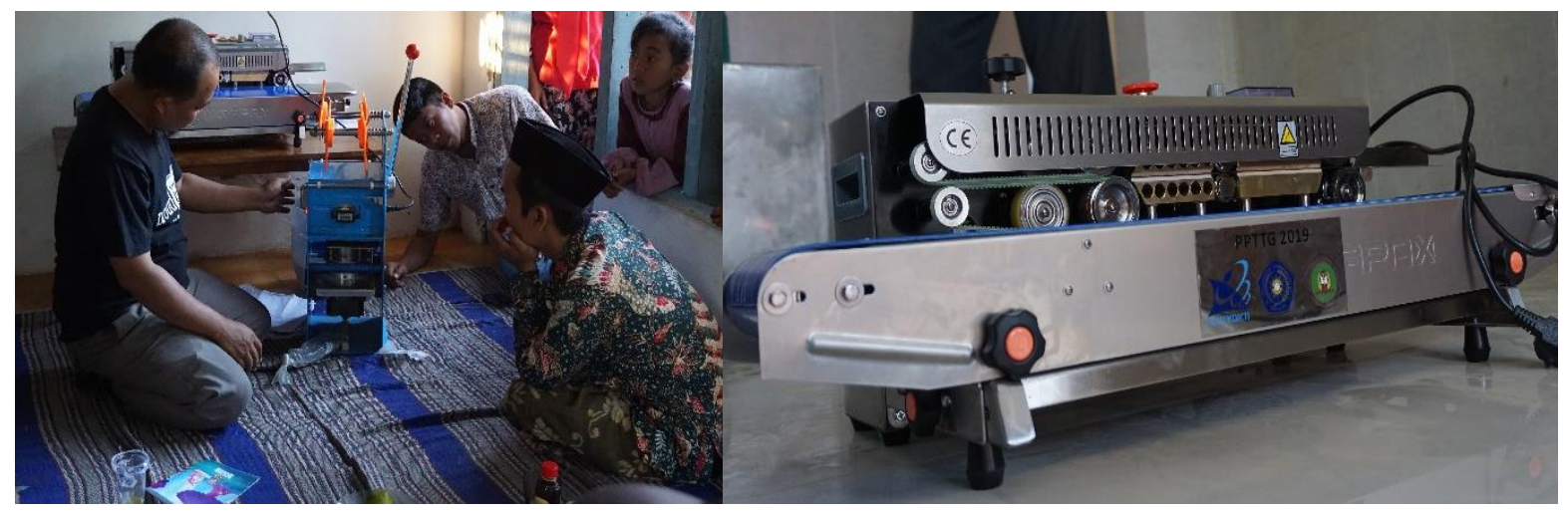

Gambar 8. Alat pres/continuous sealer yang diberikan kepada mitra

\section{Monitoring dan evaluasi (MONEV)}

Tim PPTTG melaksanakan kegiatan MONEV penggunaan TTG oleh mitra, yang difokuskan kepada keterpakaian dan kebermanfaatan TTG oleh kedua mitra. Hasil MONEV menunjukkan bahwa mitra telah menggunakan TTG secara mahir (100\% mitra mahir menggunakan TTG), mitra terlibat aktif dalam semua rangkaian kegiatan (keterlibatan mencapai 100\%), ada peningkatan kuantitas dan kualitas produk (perbandingan antara sebelum dan sesudah dilaksanakannya pengabdian sebesar 85\%), serta adanya peningkatan penjualan/omzet dari mitra dengan reraya sebesar 300\%. Gambaran poduk yang dihasilkan mitra, seperti pada Gambar 9. 


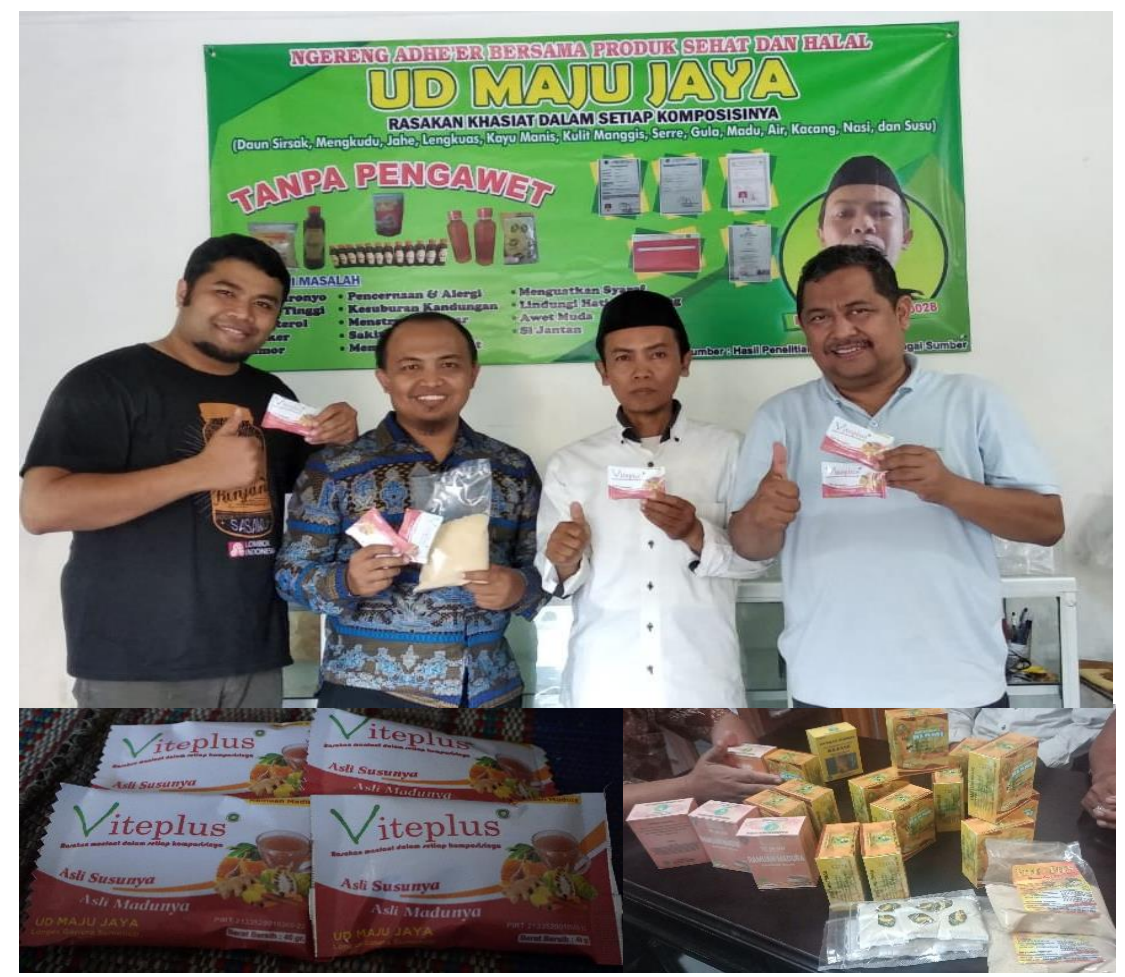

Gambar 9. Produk mitra PPTTG

Pemberdayaan IKM ramuan Madura dapat berorientasi pada strategi pengembangan usaha. Hal ini dijelaskan Muttaqin, Cahyadin, dan Widiyanti (2015) bahwa strategi yang tepat dan sesuai untuk diterapkan oleh perusahaan dalam upaya mengembangkan usahanya adalah strategi stabilitas melalui strategi hati-hati. Alternatif strategi adalah mempertahankan citra/image perusahaan, mempertahankan dan meningkatkan kualitas produk, meningkatkan jumlah dan jenis produk dengan meningkatkan diversifikasi produk, memperluas daerah pemasaran ke pasar baru, memperbaiki jalur distribusi, meningkatkan kegiatan promosi, pengembangan sumber daya manusia, mening- katkan pengendalian mutu, dan mene- rapkan teknologi yang lebih canggih.

Salah satu tantangan yang harus disikapi Indonesia adalah menguasai teknologi yang mampu menghasilkan sediaan Jamu yang aman, berkhasiat, bermutu dan praktis. Diharapkan agar dalam lima tahun ke depan, Indonesia mampu menguasai teknologi tersebut sehingga masyarakat akan makin menyukai Jamu dan dapat dimanfaatkan di fasilitas pelayanan kesehatan (Aditama, 2015).

Permasalahan yang dihadapi UKM Jamu adalah proses produksi pembuatan jamu herbal masih belum memiliki inovasi dengan pemanfaatan bahan baku terbatas untuk meningkatkan khasiatnya. UKM di Jabung maupun UKM Sukun belum menggunakan peralatan/mesin untuk mempercepat dan meningkatkan jumlah produksi. Inovasi produk juga belum ada sehingga perlu dilakukan dengan memanfaatkan gulma sebagai tambahan bahan yang bisa menjadikan produk unggulan jamu Disamping itu pemasaran yang dilakukan masih konvensional dititipkan pada kios kios jamu, tanpa ada sentuhan teknologi (Prihandarini \& Sugiarti, 2018).

Produsen ramuan atau jamu membutuhkan solusi berupa implementasikan dalam bentuk pelatihan dan pendampingan penerapan teknologi pengolahan serta perbaikan manajemen pemasaran agar tercapai peningkatan keterampilan pengolahan produk yang sesuai standar (Prawitasari \& Widjayanti, 2016). Produksi ramuan/jamu memerlukan teknologi aplikatif untuk pembuatan dan pengolahan jamu yang memenuhi standar baku mutu produk yang mengacu pada standar keamanan pangan atau standar mutu jamu (Puspita, 2014). Secara garis besar kendala yang dihadapi bagi perkembangan industri kecil yang sangat mendasar adalah lemahnya kualitas sumber daya manusia. Kendala-kendala lain yang lebih spesifik, yaitu a. Kelemahan dalam struktur permodalan dan keterbatasan sumber-sumber permodalan; b. Kelemahan dibidang organisasi dan manajemen; c. Keterbatasan dalam memanfaatkan dan penguasaan teknologi; d. Iklim usaha yang kurang mendukung karena masih adanya persaingan yang kurang sehat; dan e. Pembinaan yang kurang terpadu (Widiyanti, 2005).

Pengenalan teknologi baru relatif sama dengan program baru yang tingkat penerimaannya masih sulit di masyarakat sehingga memerlukan strategi komunikasi massa (campaign) guna memperkenalkan 
program baru tersebut ke masyarakat luas dan untuk mengubah paradigma yang berkembang, serta meningkatkan ketertarikan masyarakat untuk menggunakannya (Fathurochman, 2011). Produsen memerlukan implementasi teknologi tepat guna dalam pembuatan ramuan obat tradisional (Dwisatyadini, 2017).

Kegiatan PPTTG diawali dengan kegiatan koordinasi dan konsolidasi baik secara internal maupun eksternal. Koordinasi dan konsolidasi internal berupa penyamaan persepsi tim PPTTG, sedangkan koordinasi dan koordinasi eskternal dilakukan dengan mitra dan pihak yang dianggap memiliki dalam suksesnya kegiatan.

Kegiatan koordinasi, konsolidasi, dan bahkan konsultasi perlu dilakukan dalam pengabdian kepada masyarakat (Djiwo, Hidayat, \& Pohan, 2018; Wulan, Patmarina, Ardansyah, \& Khairuddin, 2017). Koodinasi dilakukan sebelum kegiatan utama akan dimulai (Iryani, Anwar, \& Srivani, 2018). Output dari kegiatan ini dapat berupa penegasan persetujuan dari Mitra dan kesepakatan mengenai jadwal dan waktu atau hari dan tanggal kegiatan (Rahayu, Yudi, Rahayu, \& Yuliana, 2019).

Tujuan koordinasi adalah untuk mengatur ulang jadwal kegiatan yang sudah disusun supaya sesuai dengan target yang ditetapkan (Purnomo, Martono, \& Widayati, 2018). Koordinasi ini juga diperlukan sebagai salah satu identifikasi awal untuk memastikan kebutuhan mitra. Tim pengabdian juga melakukan koordinasi internal untuk pembagian tugas dan kesepakatan tentang penyusunan materi dan bahan yang akan digunakan untuk pengabdian (Utama \& Pratama, 2017).

Sehubungan dengan itu, tim juga melakukan pendesainan TTG, mempersiapkan, dan melakukan pembuatan atau perakitan alat. Pendesainan didasarkan pada urutan kegiatan bagaimana masyarakat mempelajari sesuatu dan dalam semangat memberdayakan dan terkondisi sebagai pengalaman sehingga mereka memiliki pengetahuan dan ketrampilan pemanfaatan teknologi untuk meningkatkan kesejahteraan (Laliyo, Salim, \& Pomalato, 2014).

Tahapan berikutnya yang dilakukan tim PPTTG yaitu penyerahan, pelatihan, dan pemanfaatan teknologi oleh mitra. Menurut Djiwo et al., (2018) melalui pelatihan penggunaan dan pemeliharaan alatalat teknologi tepat guna akan terjadi transfer IPTEK. Adanya kesanggupan mitra untuk menggunakan dan memelihara teknologi tepat guna yang diberikan sesuai arahan dari tim pengabdian masyarakat menjadi hal positif akan maksimalnya manfaat kegiatan pengabdian.

Kegiatan terakhir yang dilakukan tim PPTTG adalah Evaluasi dan Monitoring secara berkalan. Menurut Sa'diah, Roosita, dan Heryanto (2015) evaluasi dan monitoring pengabdian perlu dilakukan secara berkala untuk mengetahui sejauh mana kegitan yang dilakukan dan meningkatkan kompetensi.

\section{Simpulan dan Saran}

Kegiatan pengabdian Program Penerapan Teknologi Tepat Guna (PPTTG) telah dilaksanakan dengan sangat baik, sesuai dengan target yang telah ditetapkan. Berbagai kegiatan dilakukan pengabdi, yaitu (1) koordinasi dan konsolidasi tim, serta penyamaan persepsi dengan mitra, (2) pendesainan teknologi tepat guna, penyiapan, dan pembuatan/perakitan, (3) penyerahan TTG, pelatihan, dan pemanfaatan teknologi oleh mitra, dan (4) Monitoring dan evaluasi. Kegiatan pengabdian PPTTG ini bermanfaat bagi mitra, berupa peningkatan keterampilan, semangat, kuantitas dan kualitas produksi, serta peningkatan penghasilan (income). Berdasarkan hal tersebut, ke depannya kegiatan pengabdian dengan tema atau isu terkait yang bersifat pengembangan masyarakat/daerah tertinggal perlu terus digalakkan dan didukung oleh banyak pihak.

Kegiatan pengabdian ini didanai oleh KEMENRISTEKDIKTI tahun 2019 melalui skim Program Penerapan Teknologi Tepat Guna (PPTTG). Kami menghaturkan terima kasih kepada KEMENRISTEKDIKTI atas pendanaan dan kepercayaan yang diberikan, DPPM UMM, atas segala dukungan, dan mitra (Gilang Emas dan Maju Jaya) atas kerjasama yang sangat baik sehingga kegiatan ini terlaksana sesuai rencana dan target.

\section{Daftar Rujukan}

Aditama, T. Y. (2015). Jamu \& kesehatan (1st Ed.). Jakarta: Badan Penelitian dan Pengembangan Kesehatan.

Agil, M., Wahyuni, T. S., Studiawan, H., \& Rakhmawati, R. (2019). Optimalisasi pemanfaatan herbal untuk kesehatan masyarakat Desa Wajik Kabupaten Lamongan Provinsi Jawa Timur. Jurnal Pengabdian Kepada Masyarakat, 24(4), 883. https://doi.org/10.24114/jpkm.v24i4.12515

Aladjai, E. (2019). Ramuan nenek: Pengalaman perawatan tradisional pasca persalinan Suku Banggai. Kab. 
Banggai Laut, Sulawesi Tengah: BOIS PUSTAKA.

Andriyanti, \& Wahjudi, R. M. (2016). Tingkat penerimaan penggunaan jamu sebagai alternatif penggunaan obat modern pada masyarakat ekonomi rendah-menengah dan atas Society 's acceptance level of herb as alternative to modern medicine for lower, middle, and upper class group. Masyarakat, Kebudayaan Dan Politik, 29(3), 133-145. https://doi.org/10.20473/mkp.V29I32016.133-145

Arifin, Z., Yuliawati, F., \& Syafrawi, S. (2016). IbM home industri jamu tradisional Madura untuk meningkatkan daya saing di Kabupaten Pamekasan. Jurnal Pengabdian Masyarakat J-DINAMIKA, 1(2), 92-102.

Astana, P. R. W., \& Nisa, U. (2018). Analisis ramuan obat tradisional untuk wasir di Pulau Jawa; Studi etnofarmakologi RISTOJA 2015. Jurnal Ilmu Kefarmasian Indonesia, 16(2), 115-123. https://doi.org/10.35814/jifi.v16i2.562

Burhan, B., \& Mustajib, M. I. (2010). Magang kewirausahaan pada industri kecil jamu tradisional ramuan Madura. In Prosiding Seminar Nasional Manajemen Teknologi XI (pp. 1-10). Surabaya: Program Studi MMT-ITS.

Djiwo, S., Hidayat, T., \& Pohan, G. A. (2018). Teknologi tepat guna mesin dryer packaging botol vitamin unggas skala home industri di Kecamatan Purwosari Kabupaten Pasuruan. Malang.

Dwisatyadini, M. (2017). Pemanfaatan tanaman obat untuk pencegahan dan pengobatan penyakit degeneratif. In Optimalisasi Peran Sains dan Teknologi untuk Mewujudkan Smart City (pp. 237-270). Tangerang Selatan: Universitas Terbuka. Retrieved from http://repository.ut.ac.id/7079/1/UTFMIPA2017-10-mutimanda.pdf

Fathurochman, M. A. (2011). Perancangan campaign program saintifikasi jamu Balai Besar Penelitian Dan Pengembangan Tanaman Obat Dan Obat Tradisional. Jurusan Desain Komunikasi Visual, Fakultas Sastra dan Seni Rupa, Universitas Sebelas Maret.

Fatmawati, I. P., Anwari, A. H., Harun, M., \& Alwiyah, A. (2013). Kelayakan agrowisata jamu ramuan Madura di Kabupaten Sumenep. Jurnal Pertanian Cemara, 12(1), 10-13. https://doi.org/10.24929/fp.v10i1.29

Handayani, S. (2008). Islam, kesehatan dan lingkungan hidup: Studi tentang jamu Madura. KARSA, 14(2), 161-174.

Iryani, N., Anwar, S., \& Srivani, M. (2018). Pembuatan laporan keuangan perusahaan kepada UKM Tungku Sanjai dan Karak Kaliang DARSI Piladang Kecamatan Akabiluru Kabupaten 50 Kota. Payakumbuh.

Laliyo, L. A. R., Salim, S., \& Pomalato, S. (2014). Rekayasa implementasi teknologi tepat guna melalui pengembangan model pembelajaran untuk menumbuhkan budaya pemanfaatan energi terbarukan pada masyarakat daerah terpencil. Gorontalo.

Limananti, A. I., \& Triratnawati, A. (2003). Ramuan jamu cekok sebagai penyembuhan kurang nafsu makan pada anak: Suatu kajian etnomedisin. Makara Kesehatan, 7(1), 11-20.

Mudjijono, M., Herawati, I., Munawaroh, S., \& Sukari, S. (2014). Kearifan lokal orang Madura tentang jamu untuk kesehatan ibu dan anak. Yogyakarta: Balai Pelestarian Nilai Budaya (BPNB).

Muslimin, L., Wicaksena, B., Setiyawan, B., Subekti, N. A., Sukesi, H., Surachman, H., ... Khaidir, K. (2009). Kajian potensi pengembangan pasar jamu. Jakarta.

Muttaqin, H., Cahyadin, M., \& Widiyanti, E. (2015). Pemberdayaan usaha jamu jahe instan di Kota Surakarta dan Kabupaten Sukoharjo melalui teknologi pengolahan jahe. Inotek, 19(2), 124-138.

Nurlaila, S. (2013). Jamu Madura: Eksistensi, ekspektasi dan realitas pengembangannya dalam perspektif produsen dan konsumen. MADURANCH: Jurnal Ilmu Peternakan, 10(10), 45-54. 
Nurwidodo, N. (2006). Pencegahan dan promosi kesehatan secara tradisional untuk peningkatan status masyarakat di Sumenep Madura. Humanity, 1(2), 96-105.

Pelokang, C. Y., Koneri, R., \& Katili, D. (2018). Pemanfaatan tumbuhan obat tradisional oleh Etnis Sangihe di Kepulauan Sangihe Bagian Selatan, Sulawesi Utara. JURNAL BIOSLOGOS, 8(2), 45-51.

Prastiwi, R. S. (2018). Pengobatan tradisional (jamu) dalam perawatan kesehatan ibu nifas dan menyusui di Kabupaten Tegal. Jurnal SIKLUS, 7(1), 263-267.

Prawitasari, S., \& Widjayanti, F. N. (2016). Pemberdayaan perempuan pengrajin jamu melalui teknologi diversifikasi produk jamu tradisional serta manajemen pengelolaan usaha. Pengabdian IPTEK, 1(1), 91-96. https://doi.org/10.32528/pengabdian_iptek.v1i1.183

Prihandarini, R., \& Sugiarti, U. (2018). Inovasi jamu herbal berbasis gulma. In Conference on Innovation and Application of Science and Technology (CIASTECH 2018) (pp. 244-251). Malang: Universitas Widyagama Malang.

Purnomo, B., Martono, B., \& Widayati, W. (2018). Pemberdayaan guru pos PAUD Terpadu (PPT) Kuncup Ceria $R W V$ Kelurahan Wonokromo, Surabaya tentang pembelajaran aktif, inovatif dan menyenangkan. Surabaya.

Puspita, R. (2014, September). Jamuku lestari jamu kita membumi. GO WRITING!, 1-20.

Rahayu, S., Yudi, Y., Rahayu, R., \& Yuliana, Y. (2019). Peningkatan akuntabilitas pengelolaan bahan habis pakai sekolah. Jurnal Karya Abdi Masyarakat, 3(1), 9-14. https://doi.org/10.1017/CBO9781107415324.004

Ratnawati, S., Handayani, D., \& Rakhmawati, R. (2013). Pengembangan tradisi meramu jamu sehat wanita madura dalam upaya meningkatkan kesehatan masyarakat. Mozaik, 13(1), 74-87.

Ratnawati, S., Jurianto, J., \& Ali, M. (2017). Jhemo Madura: Kearifan lokal dalam tantangan global. In International Seminar on Language Maintenance and Shift (LAMAS) (pp. 655-660). Semarang: Master Program in Linguistics, Diponegoro University in Collaboration with Balai Bahasa Jawa Tengah. https://doi.org/10.1016/B0-08-044854-2/01289-X

Retnowati, N., \& Kurniawati, D. (2016). Pengembangan usaha IKM jamu tradisional di Kecamatan Sumbersari dan Kaliwates Kabupaten Jember. In Seminar Nasional Hasil Penelitian dan Pengabdian Masyarakat (pp. 162-167). Jember: Politeknik Negeri Jember. Retrieved from https://publikasi.polije.ac.id/index.php/prosiding/article/view/202

Sa'diah, S., Roosita, K., \& Heryanto, R. (2015). Pemberdayaan kelompok ibu-ibu PKK Desa Babakan, Kecamatan Darmaga, Kabupaten Bogor dalam upaya swamedikasi menggunakan tanaman obat. Agrokreatif Jurnal Ilmiah Pengabdian Kepada Masyarakat, 1(1), 62. https://doi.org/10.29244/agrokreatif.1.1.62-67

Safrizal, H. B. A., \& Kurriawati, N. (2016). Peningkatan kinerja usaha kecil jamu Madura: Pemanfaatan teknologi informasi. Kompetensi, 10(1), 1-8.

Satriyati, E. (2016). Pola tradisi minum jamu: Upaya pemertahanan pengobatan lokal sebagai identitas masyarakat Bangkalan Madura. Dimensi, 9(2), 115-122.

Satriyati, E. (2017). Menjaga tradisi minum jamu Madura dengan penyampaian pesan interpersonal kesehatan antara peramu dan pengguna. DIMENSI - Journal of Sociology, 10(2), 24-35. Retrieved from http://journal.trunojoyo.ac.id/dimensi/article/download/3757/2758

Savitri, E. S. (2016). Uji antifungi ramuan tradisonal Madura "Subur Kandungan." Al-Kauniyah Jurnal Biologi, 8(1), 1-5. https://doi.org/10.15408/kauniyah.v8i1.2698 
Shanthi, R. V., Jumari, J., \& Izzati, M. (2014). Studi etnobotani pengobatan tradisional untuk perawatan wanita di masyarakat Keraton Surakarta Hadiningrat. Biosaintifika: Journal of Biology \& Biology Education, 6(2), 61-69. https://doi.org/10.15294/biosaintifika.v6i2.3101

Simanjuntak, H. A. (2016). Etnobotani tumbuhan obat di masyarakat etnis Simalungun Kabupaten Simalungun Provinsi Sumatera Utara. BioLink Jurnal Biologi Lingkungan, Industri, Kesehatan, 3(1), 75-80.

Susanti, N. (2016). Aktivitas antimikroba ekstrak rimpang jeringau (Acorus calamus) terhadap $\begin{array}{lllll}\text { pertumbuhan } \quad \text { Candida } & \text { albicans. Jurnal }\end{array}$ https://doi.org/10.15575/biodjati.v1i1.1037

Susila, K. A., Tellu, A. T., \& Tangge, L. (2017). Jenis dan pemanfaatan tanaman obat di Desa Tinading dan pengembangannya sebagai media pembelajaran. E-JIP BIOL, 5(2), 60-70.

Utama, A. A. G. S., \& Pratama, D. (2017). Pengabdian masyarakat Desa Taman Sari: Optimalisasi kinerja UMKM melalui pelatihan akuntansi sederhana. In Seminar Nasional Hasil Penelitian dan Pengabdian kepada Masyarakat UNIPMA (pp. 357-360). Madiun: UNIPMA. Retrieved from https://semnas.unikama.ac.id/lppm/prosiding/2017/Pengabdian/45.Raymond_Nanik_Pengabdian_ Ekonomi_dan_bisnis.pdf

Widiyanti, H. (2005). Sejarah perkembangan industri jamu tradisional dan pengaruhnya terhadap kehidupan sosial ekonomi masyarakat Gentasari Kecamatan Kroya Kabupaten Cilacap tahun 19902002. Jurusan Sejarah, Fakultas Ilmu Sosial, Universitas Negeri Semarang.

Wulan, S., Patmarina, H., Ardansyah, A., \& Khairuddin, K. (2017). Prosedur pendirian koperasi. Kegiatan Pendampingan Pendirian Koperasi bagi Kelompok Industri Rumah Tangga Pengrajin Emping di Kelurahan Suka Maju Kecamatan Teluk Betung Timur Kota Bandar Lampung, dalam bentuk kegiatan: Koordinasi, Konsolidasi dan Konsultasi. Bandar Lampung.

Zaman, M. Q. (2009). Etnobotani tumbuhan obat di Kabupaten Pamekasan Madura Provinsi Jawa Timur. Jurusan Biologi, Fakultas Sains dan Teknologi, Universitas Islam Negeri (Uin) Maulana Malik Ibrahim Malang. 